This is an electronic reprint of the original article. This reprint may differ from the original in pagination and typographic detail.

Author(s): Auvinen, Tommi; Lämsä, Anna-Maija; Sintonen, Teppo; Takala, Tuomo

Title: $\quad$ Leadership Manipulation and Ethics in Storytelling

Year: $\quad 2013$

Version:

Please cite the original version:

Auvinen, T., Lämsä, A.-M., Sintonen, T., \& Takala, T. (2013). Leadership Manipulation and Ethics in Storytelling. Journal of Business Ethics, 116(2), 415-431.

https://doi.org/10.1007/s10551-012-1454-8

All material supplied via JYX is protected by copyright and other intellectual property rights, and duplication or sale of all or part of any of the repository collections is not permitted, except that material may be duplicated by you for your research use or educational purposes in electronic or print form. You must obtain permission for any other use. Electronic or print copies may not be offered, whether for sale or otherwise to anyone who is not an authorised user. 
This is a manuscript version of an article whose final and definitive form has been published in Journal of Business Ethics 116 (2), 415-431.

\section{Leadership Manipulation and Ethics in Storytelling}

Tommi Auvinen, Anna-Maija Lämsä, Teppo Sintonen \& Tuomo Takala

ABSTRACT: This article focuses on exerting influence in leadership, namely manipulation in storytelling. Manipulation is usually considered an unethical approach to leadership. We will argue that manipulation is a more complex phenomenon than just an unethical way of acting in leadership. We will demonstrate through an empirical qualitative study that there are various types of manipulation through storytelling. This article makes a contribution to the literature on manipulation through leadership storytelling, offering a more systematic empirical analysis and a more nuanced view of the topic than previously existed by outlining how managers engage in manipulative storytelling and what kind of ethics they link to their manipulation in leadership. Four types of manipulation in storytelling are identified in the study: humorous, pseudo-participative, seductive and pseudo-empathetic. From an ethical perspective we will show that manipulation is not always self-evidently reprehensible. We will conclude that the dominant ethical justification for manipulation stems from its consequences.

Key Words: leadership, ethics, unethical, manipulation, storytelling, narrative, narration, social constructionism 


\section{Leadership M anipulation and Ethics in Storytelling}

\section{Introduction}

The basic tool for the manipulation of reality is the manipulation of words. If you can control the meaning of words, you can control the people who must use the words. Philip K. Dick in How To Build A Universe That Doesn't Fall A part Two Days Later (1978)

Leadership researchers have spent considerable time and effort on defining the meaning of leadership. However, according to Ciulla (1998), if we look at samples of definitions historically we see that leadership does not mean radically different things for different scholars. Leadership is typically viewed as an influence process between leaders and followers. Yukl (2010) also argues that despite the large number of definitions it is useful to understand leadership as a process of influence. Recently, our understanding of leadership has turned increasingly on the discursive resources deployed by leaders such as storytelling in the influence process (e.g., Gabriel, 2008; Fairhurst, 2008; Boje et al., 2011).

Since most definitions view leadership as some kind of influence process, it raises a question about the nature of influence. According to Ciulla (1998), the ultimate interest in the field of leadership should not only be a question what are effective methods for exerting influence but what but what is the ethics of leadership. Rhode (2006) suggests that ethical leadership refers to exercising influence in ways that are ethical in means and in ends. Unethical leadership can for its part be considered unethical in means and ends. 
In this article we focus on a particular way of exerting influence in leadership, i.e. manipulation through storytelling. Manipulation can be defined as a way of exerting influence in which the target does not know that she or he has been influenced (Mills 1990 [1959]). Manipulation is usually considered unethical of leadership (Bass 1998; Bass and Steidlmeier, 1999; Brown and Trevinõ, 2006). In fact, Bass (1998) says that manipulative leaders can be called pseudo-ethical leaders. However, we think that manipulation in leadership is a more complex phenomenon than just one unethical way of acting. Thus, a starting point of our article is that manipulation in leadership can be a diverse phenomenon. The article makes a contribution to literature on manipulation through storytelling not only offering a systematic empirical analysis but also a more nuanced view on the topic, outlining how managers engage in manipulative leadership and what kind of ethics they link to their behaviour.

We draw upon social constructionism in this article (Berger and Luckmann, 1966; Fairhurst and Grant, 2010) by studying managers' storytelling as a form of manipulation in their leadership. A part from the traditional views of leadership which tend to fix leadership in the person, the situation, or person-situation combinations, we see leadership as a socially and culturally constructed phenomenon which is created through language use and communication (Lämsä and Sintonen, 2001; Fairhurst and Grant, 2010; Fairhurst, 2008, 2011). In an organizational context, which is our focus here, leaders aim to influence employees through the narrative form to create a particular social reality, for example, to engage employees, make a vision meaningful, to legitimise a leader's own role and ideas etc. This process can be called a meaning making process which aims to make 
something real and meaningful in the followers' minds (Fairhurst, 2011).

The aim of this article is to identify through an empirical study, different types of manipulation in leadership though storytelling. In particular, we are interested in what kind leadership reality managers are producing (Fairhurst, 2008, 2011) while telling mani pulative stories in their leadership. Our research questions are as follows:

- What kind of manipulative stories do managers tell to influence their employees?

- How do managers themselves say that manipulation takes place in their storytelling?

- Why do managers tell manipulative stories to influence their employees?

- What kind of ethics do managers reveal when telling manipulative stories to influence their employees?

According to Brand (2009), quantitative research has predominated in business ethics research and there is an urgent need for greater diversity of approaches and specifically for qualitative studies. Therefore, this paper takes up this challenge by investigating the topic through a qualitative, particularly narrative, approach. We have acquired authentic data about manipulation in storytelling by interviewing managers. Brown et al. (2009) state that stories are deeply implicated in organizational life and scholarship. They ( $p$. 3025) argue that stories are "always replete with meaning, often containing moral judgments" and emotional reactions. Driscol and McKee (2007) suggest that storytelling by leaders, which integrates a moral and spiritual component, can transform 
organisational culture so that the members of an organisation begin to feel connected to a larger community and a higher purpose. In this sense storytelling has a positive moral aspect. However, Driscol and McKee (2007) also raise the concern of the potential dark side of storytelling by leaders by arguing that caution has to be taken whenever there is a discussion of the emotional and moral influence of stories on employees. An employee being controlled by a manager through manipulative storytelling raises doubts about ethics of such an approach.

In general, in leadership literature the role of storytelling is seen as increasingly important for both practice and research (Boje, 1991, 1995, 2001; Dennehy 1999; Gabriel 1995; 2000). Boje (2006; also see Auvinen 2012) argues that storytelling in practice has progressed without a meaningful and close connection to academic work on storytelling and not too many empirical studies on storytelling in leadership exist. Storytelling has been argued to embody classical qualities of leadership and virtue. Particularly the more pragmatic orientation in leadership often considers storytelling as an effective means for influencing, for example, an effective means to advance organizational change or to inspire employees. (e.g. Collinson and Mackenzie, 1999; Denning, 2004; Parkin, 2004; Brown et al., 2005). More recently challenges such as ethics and pitfalls in storytelling leadership have been considered to some extent (e.g. Boje, 2006; 2008; Poulton 2005; Parry and Hansen, 2007). For example, Boje (1999) and Gabriel (2008) raise a concern about transparency in narrative influence. Collective, organizational memory can be panoptic - transparent only in one direction. Storytelling can al so be a way to forget what is not convenient to recall or to embellish historical accounts (Gabriel, 2008). 
This article proceeds as follows. First, we will introduce our theoretical background and define the salient concepts (storytelling, manipulation, leadership and ethics). Second we will move on empirical part, introducing the empirical data and methodology and the analysis of the data. We then present our results. Last, we make conclusions and suggest ideas for the future research and action.

\section{Theoretical background}

\subsection{Storytelling leadership}

Many influential leaders has been said to be great storytellers (Ciulla, 2005). Peters (1990, p. 15) even argues that "[t]he best leaders - of nations as well as corporations and volunteer groups - have always been the best storytellers". Often charisma, (effective) leadership and storytelling are intertwined (Boje, 1999; Gabriel, 2000; Denning, 2004, 2005). Even Plato stated that those who tell stories rule society (Fisher, 1985). A person, who narrates the story of the organization, shapes a shared social reality (Lehtonen, 2004). Hence storytelling is not about coercion. Influencing employees is constructed in an interpretation of the stories in the organization.

Boje (e.g. 1991, 1995, 2008) argues that storytelling is the work of leadership and the behaviour of the organization. All leaders tell stories - "some with all the rhythms and charisma of oral storytellers, others whose anecdotes are bureaucratic refrains, but all become part of the collective and storied memory that is organizations" (Boje, 1999; see 
also Boje 2003a). In storytelling leadership a human being is fundamentally seen as a storyteller who constructs stories in order to get a grip on our chaotic reality (M clntyre 2007 [1981]; Auvinen, Mangeloja and Sintonen, 2010) and, thus, every organization is a storytelling organization (Boje, 2008). Storytelling is the preferred sense-making and currency of human relationships (Boje, 1991; Bruner, 1991). For example, a leader crafts stories to integrate disparate organizational elements and to make sense of the present retrospectively (Weick, 1995, p.61; Boje, 2003b) or to convince followers by backing up statistical measurements in complex situations (Jameson 2001; Auvinen 2012).

According to Boje (1999), leadership theory was very much rooted in storytelling in the beginning of its history. However, the theory quickly turned away from its narrative roots. More recently, organization and leadership studies have been criticized for being late in taking an interest in the stories that people tell in and about organizations (Gabriel and Griffiths, 2004; Denning, 2005). Even if stories are attracting increasing attention from among organization and leadership researchers today (Taylor et al., 2002; Gergen and Gergen, 2006), their significance, role and function in leadership practice have remained relatively uncertain, complex and under-researched (Boje, 2006; Sintonen and Auvinen, 2009). Storytelling and leadership through narrative still remain under-researched and more empirical studies are needed (e.g. Boje and Rhodes, 2006; Auvinen, Aaltio and Blomqvist 2012).

The terms 'story' or 'narrative' are equivocal and no single definitions exist (e.g. Polkinghorne, 1988; Brown et al., 2009). In this study we follow Polkinghorne (1988) and 
understand a story as a narrative. We define a story as an oral or written communicative act where particular events occur over time, thus any story has a chronological dimension (Søderberg, 2003). When a manager recounts events related to her/ his manipulation, she/ he integrates them retrospectively into her/ his leadership. Leadership storytelling for its part is viewed here as a narrative process, where particular leadership intention is actualized in storytelling (cf. Auvinen et al. 2012). That is, a manager resorts to telling stories with a view to exerting influence on employees.

Storytelling in leadership is preferably more democratic than coercive manipulation and differs from argumentation since storytelling does not aim at instant (yes/ no) solutions (Weick and Browning 1986). Unlike argumentation, storytelling is available and open to all organizational members. Moreover, storytelling differs from commands because it does not necessary require instant action. In other words, storytelling is a relatively open influence process - which is also open to manipulation.

\section{$2 \mathrm{M}$ anipulation in leadership}

In the old myths many heroes and great leaders swindled opponents ruthlessly on behalf of their crew. For instance 0 dysseys was completely crooked as were the many characters from the Bible, and neither were archetypes of trustw orthiness the heroes of Kalevala (Lauerma 2006, p.28)

Manipulation has many aspects and the debate concerning the definitions of manipulative behaviour and related concepts (such as lying) are complex (Bok, 1981; Carson, 1988; Wrong, 2004). However, a commonly accepted definition is that manipulation is about 
influencing someone so that she or he does not know the intention of the manipulator (Mills, 1990 [1959]; Wrong, 2004). In this article we understand manipulation as a discursive means used by managers for the purpose of the concealed influence of employees. In addition, we focus on stories as a type of discursive practice. This rather broad definition needs, however, some clarification. First, we need to know what the forms and means of manipulation are. Second, manipulation has an ethical dimension. Does manipulation imply lying or cheating? Is manipulative leadership automatically the most unethical option? These questions are discussed next.

Manipulation can be understood as an umbrella concept for some forms of intentional behaviour, such as lying or misleading (e.g. distributing disinformation). The definitions of lying suggest that it has something to do with conceal ed influence on people. Bok (1981, p. 33) sees lying as any intentional deceptive message, which is possible to formulate in words. Carson (1988, p. 511) expands the conditions of Iying as a deliberate false statement which contains at least one of the following: (1) intended to deceive others, (2) foreseen to be likely to deceive others, or (3) a statement which one has, in some sense, promised or guaranteed to be true. Disinformation for its part refers to the sharing of truthful but purposefully misleading information while misinformation refers to the distribution of false information (Lauerma, 2006, pp. 12-20). In both cases, information may be presented in a way that it provides misleading conceptions to the receiver. Even providing too much (truthful) information may relate to intentional manipulation too, since it may disrupt the finding of relevant information. Whether it is a matter of lying, dis- or misinformation, stories mediate all of them. 
Influencing someone is a social action which has meaning. Furthermore, a meaningful action requires a medium through which meanings can be communicated. Thus, manipulation can be based on spoken or written language use and it is mediated discursively. Telling stories is a discursive action which functions as a medium for manipulation. As Riessman (2008) states, stories can serve many kinds of purposes for individuals, they may help us to remember past events, justify our arguments, entertain our friends, and most importantly, we may persuade, engage and mislead our fellow people. Gabriel $(2008,154)$ adds, that it is a kind of agreement in storytelling which exists in social affairs: "Storytellers have always enjoyed a licence to embroider and embellish their accounts, even at the cost of sacrificing historical accuracy. Manipulation as a discursive act of influencing exploits these features of stories.

It is argued that the great leaders have always led their troops by manipulating the line between normal and abnormal and desirable and undesirable - and the emphasis in exercising power has shifted from mediaeval coercive to more mental and psychological forms of power use in modern societies (Foucault 1980 [1975]; A honen 2001). Traditionally leadership research treats influence and power as distinct processes emphasizing the leader's power over followers. Often power is associated with forced compliance whereas influence is associated with voluntary compliance and is usually regarded as the very embodiment of leadership. The storytelling approach adopted in this paper eschews a power-influence dualism and integrates both perspectives. (Fairhurst, 2011.) Since manipulation can be a way of influencing, it is al so related to the use of power. 
Wrong (2004) categorizes manipulation as one of the four types of power use. The three others are persuasion, coercion and legitimate authority. According to Wrong, manipulation can be effectively used when supplemented with the other forms of power. In organizational life manipulation is exercised to produce the intended outcomes by the power wielder. In terms of power, manipulation occurs when the power holder conceals her/ his intent from the power object. Such an exercise of power is less likely to provoke resistance because the object, for example, an employee, is unaware of the exertion of power. As Lukes $(2005,1)$ states, "power is at its most effective when least observable". Storytelling is a salient means of manipulation because influence can be conceal ed into the commonplaceness of the conventions of stories. Adapting Wrong's (2004, p. 29) idea, manipulative leadership may be even an act in which a leader presents and delivers information to aid or encourage the employee to pursue her/ his own goals.

In general, leadership often has positive moral connotations embedded and mostly literature on the topic has focused on the constructive side of leadership (Tierney and Tepper, 2007). There is an overwhelming number of discussions focusing on successful leadership such as transformational, authentic, servant, heroic and charismatic leadership (Ciulla, 2005). The negative face of leadership is also recognized, referring to such characteristics as narcissism, a failure to reflect, mirroring, emotional illiteracy and an unwillingness to let go (Kets de Vries, 1993). Being phoney and not genuine, which are often associated with manipulation, are also features which are considered as belonging to the dark side of leadership. By focussing on manipulation we are more likely to be digging 
around in the dark side of leadership than the positive side since whenever there is an employee who is influenced by a leader through manipulative storytelling, doubts about the ethics of this arise (Driscol and McKee, 2007). For instance, according to Ciulla (1998; Rost, 1993), the most ethically attractive ideas of leadership imply a participatory and democratic relationship between leaders and followers as well as recognition of the values and needs of the followers. The most ethically unattractive ideas are those that appear to be coercive and manipulative.

Despite some exceptions the over-riding theme in studies on leadership and ethics is that leadership involves a moral purpose, and the common idea in the literature is that the efforts of leaders are well intended (Clements and Washbush, 1999; Ciulla, 2005). However, in their efforts to influence, to make inspiring appeals, to create and maintain the enthusiasm of employees, many leaders may be manipulative. They may publicly support, but in secret oppose proposals. They may have the image of a saint in public, but privately be devils. They may hide important matters from employees to achieve personal benefits. (Bass, 1998.)

Professionals must sometimes do harm in order to do good, and tasks that require people to do harm in the pursuit of good are a ubiquitous part of professional work (Molinsky and Margolis, 2005). Journalists, managers, salespersons, lawyers and administrators take the deviation of the truth often even as self-evident (Bok, 1981). In everyday leadership routines such as evaluations and assessments, the leader may try to avoid insulting 
her/ his subordinates. Demarcation between honesty and deceit seems to be extremely challenging and consistent procedure, unreachable.

To sum up, as Bok (1981, 15-17) states there is a clear gap in moral theory: There is no theory for moral choices which would help when we hesitate before we speak the truth or tell a lie. This relates very much to leadership due to its interactional and power related nature - and the way leadership influence is produced (McClelland, 1970). Since manipulation is not simply a matter of telling the truth or a lie as such. What counts is that in manipulation, leaders may use stories, which they themselves consider false. A ppealing to traditional theories of truth does not give a satisfactory answer. It is almost impossible to show that a told story corresponds to some kind of reality, since we are neither sure nor unanimous about the quality of reality. However the ambiguity and uncertainty of reality cannot be used as an excuse for manipulation. (Bok, 1981.) In a moral sense, the question of true/ false has importance for the everyday practice of leadership. Adhering to the truth might be a good investment in the long run for at least two reasons: a reputation as a trustworthy leader is valuable social capital (Lauerma, 2006), and rather than basing on outcomes, moral judgements should be based on the right moral principles (Ciulla and Forsyth 2011, p. 233). Furthermore, intentional cheating and lying can be aimed at selfseeking or a false image of self, but in any case a liar might reveal desires, intentions and other matters that he would like to hide most - concerning both the leader's own and his organization's weaknesses. Ultimately, the leader influences the ethical culture of the whole organization. 


\subsection{Ethics and leadership}

In this article we rely on Ciulla's (2005; Ciulla and Forsyth 2011) framework while detecting ethics in managers' manipulative storytelling. Ciulla's framework looks at leadership ethics through a variety of philosophical viewpoints, based on traditional ethical theories which stress individuality and rationality. The framework offers a criteria for analysing manipulative leadership from different ethical angles, thus, allowing us to use theoretical triangulation (Bryman and Bell, 2007) - a variation of multipletheories. For example, Kujala et al. (2011) argue that to be able to capture the characteristics of managers' ethical orientation as fully as possible, theoretical frameworks applied in empirical research should be multidimensional.

According to Ciulla and Forsyth (2011, p. 239), there are three facets to the ethics of leaders:

1) What a leader does? This refers to the consequences of a leader's actions (Mill).

2) How a leader does things? This refers to the virtues/vice of a leader's actions (A ristotle).

3) Why a leader does things? This refers to a leader's ethical duties (Kant).

The first facet, the consequences of a leader's actions, draws particularly from utilitarianism, a teleological approach in ethics (Ciulla, 2005, 2011, p. 238-239). The basic principle of utilitarianism is that "an action is morally right if it results in the greatest amount of good for the greatest number of people affected by the action" (Crane and Matten, 2004, p. 84). Utilitarianism thus stresses the moral principle of seeking the greatest 
happiness for the greatest number of people that is also part of job description of most leaders. Utilitarianism puts at the centre of evaluation the value of actions that is 'utility' (Velasquez, 1998, p. 84). Action is morally correct when after analysing its good and bad effects for people involved; the greatest utility is a result of this action. Based on the argument by John Stuart Mill (see Ciulla and Forsyth, 2011, p. 238) most people do not make utilitarian judgements that concern everyone around the world but rather make choices based on what is good for a specific group of people. So, it seems sensible to think that a leader's job is to find the greatest good for her/ his constituents. According to utilitarianism, manipulation in leadership may be applied when an action is more or less justifiable according to the consequences (Bok, 1981). However, we could assume that a utilitarian person always aims at some kind of benefit or profit, material or ideal. Manipulative utilitarian people try to reach their own goals at the cost of others, if this kind of action is regarded as being the most promising. Thus they could be self interested people, never motivated by altruistic motives. A benevolent utilitarian manipulator seems to be a contradiction in itself.

The second facet refers to the process of leadership. This is about the means that a leader uses to influence. According to Ciulla and Forsyth (2011), the process of leadership is connected to the ideas of Aristotle, an advocate of virtue ethics. A person has a moral virtue, an acquired disposition, when the person, i.e. a leader is disposed to behave in the way that virtue demands, and with the reasons and desires that are features of a morally good person. Virtue ethics takes virtues such as honesty, courage, integrity, self-control, humanity and vices such as dishonesty, greed, lack for integrity as the basic starting point 
for ethical reasoning. (Velasquez, 1998, p. 132.) Aristotle claimed that virtues are a golden means between extremes, and excess and deficiency represent vices. The evaluation of both is also context dependent and this influences what is prudent and realistic behaviour in a particular situation (Wicks et al., 1999). Moreover, virtue theory argues that the main aim of a moral life is to develop moral virtues and to exercise and exhibit them in the many situations that human life sets before us (Velasquez, 1998, p. 136). According to virtue ethics, the job of leaders is to make their constituents happy or at a minimum, to try not to make them unhappy (Ciulla and Forsyth, 2011, p. 238). Ciulla and Forsyth contend that happiness is not a pleasure but rather it is an expansive notion of learning and growing.

The third facet relates to a leader's moral intentions, which is the focus of deontology. This refers to a leader's moral intentions and particularly to the role of duties as a basis for leadership. Kant, the advocate of deontology, saw people as rational actors who can make their own rational decisions about what is right and wrong. Moreover, Kant described specific duties for all people which should be followed to facilitate moral action. A leader's morality is based on her or his duty. (Crane and Matten, 2004, p. 86-87.) According to Kant, while making moral choices a leader should follow the categorical imperative. This principle is related to the golden rule. It says, make choices based on how you want everyone else to choose if they were in your place. (Ciulla and Forsyth, 2011, pp. 237-238.) So, if a leader decides to lie in a specific situation, he must also accept other people, i.e. employees will lie in a similar situation. Another Kant's maxim is that "act so that you 
treat humanity, whether in your own person or in that of another, always as an end and never as means only" (Crane and Matten, 2004, p. 87).

\section{Method of the study}

Our research strategy is qualitative and we draw particularly on narrative inquiry (see e.g. Gabriel, 1995; Jameson, 2001; Auvinen, et al. 2012). The data consists of qualitative, thematic interviews which contain stories managers have told with a view to influence their employees. In this study, our narrative configuration has to do the analysis of narratives, which, adopting Polkinghorne (2007), mean the studies whose data consist of stories and which are concerned with analysing according to typologies or categories. In other words, stories told by the interviewed managers are analysed by categorizing the stories and then producing a typology of manipulation in managers' storytelling.

To reach a rich view of the topic, a heterogeneous group of managers was interviewed. We applied purposeful sampling (Patton, 2002) to select managers. A common characteristic shared by the interviewees was their leadership position in the organization. Furthermore, all managers were either publicly known (through the media) as good storytellers or recommended by their employees and colleagues for the same reason. In the first phase of the study we conducted 18 open-ended interviews creating a sample comprising of 7 female and 11 male managers. Their age varied from 26 years to 70 years and work experience from 2 years to 40 years. The managers worked in different lines of businesses such as industry, research, public administration and banking. The managers represented all managerial echelons - CEOs, middle managers and supervisors. The interviews were 
thematic (Steinar, 2007; Eskola and Suoranta, 1998).

We invited the managers to retell stories they themselves had told in their organizations with a view to exerting influence on their subordinates. The interviews induded such themes as the manager's self-image as a leader and examples of storytelling in her/ his leadership. Furthermore, managers' opinions on different leadership styles such as democratic and authoritarian were also discussed. All the interviews were conducted in Finnish since the data was gathered in Finland. Therefore all the quotations presented in this article are translations. The interviews were recorded and transcribed word for word. The duration of each interview was between 45 min to 1.5 hours.

Since our research task was related to manipulation, we then read the interview data carefully to detect manipulative stories. We detected such stories in 9 managers' interviews (out of 18), thus the other 9 interviews were excluded from the data since we found no signs of manipulation in them. Consequently, 9 interviewees were included in our final sample comprising 4 female and 5 male managers. Their age varied from 35 years to 65 years and work experience from 8 to 40 years. They represented different managerial levels in different organizations (see Table 1). Due to anonymity promised to the interviewees each manager was assigned a code A, B, C, D, E, F, G, H and I. The codes are used later on in this article to refer to each particular manager. In these managers' interviews 13 manipulative stories were found. The stories are also numbered from 1-13. Some of the stories are coherent narratives meaning that the stories have a chronological dimension and a clear plot (Søderberg, 2003) while some stories are in a more terse and 
fragmented form (Boje, 2001).

At the first phase of the analysis we started to read through the data carefully. In the second phase, after getting acquainted with the data as a whole, we began to discuss and share our first impressions of the issues and dissected the data collectively. We aspired to identify all leadership storytelling situations related to manipulation according to our definition. A thematic analysis (Riessman, 2008; Eskola and Suoranta, 1998) was used to identify the areas of manipulation in leadership storytelling. Manipulation in storytelling was revealed by a manager's descriptions of the situation and her/ his intention, bearing in mind our definition of manipulation in this paper - that the manager's intention of telling the particular story has to do with concealed influence (dis/misinformation or straightforward lying) (Wrong, 2004; Mills, 1990 [1954]; Bok, 1981; Lauerma, 2006).

In the course of the analysis, we circulated the data and organized several common joint analysis sessions. Hence, methodological triangulation is involved in the analysis process at least in the following two senses: (1) the researchers circulated data and ideas (Flick 2007), and (2) the analysis proceeded by an interaction between empirical data and the researchers' theoretically-based interpretations (Eriksson and Kovalainen, 2008; Eskola and Suoranta, 1998; Riessman, 2008). As a result of this process we detected 13 manipulative stories numbered from 1-13 and constructed then four types of manipulative leadership from the stories: 
- humorous - stories are 1) a hanged chef in the hotel, 2) a chef without thumbs in the old days in a logging cabin, 3) a less harmful engineer, and 4) Croatian female guerrilla

- pseudo-participative - stories are 5) annual strategy meeting day, and 6) Oldsmobile car manufacturer

- $\quad$ seductive - stories are 7) cut-glass chandelier, 8) poppy fabric for curtains, 9) poor working circumstances, and 10) my kid's hut,

- pseudo-empathetic - stories are 11) the lies of angels, 12) tearful subordinate, and 13) dyslexic supervisor.

Finally, in the analysis, we considered all the stories in terms of Ciulla's (2005; Ciulla and Forsyth 2011) three facets to the ethics of leaders. Every story was inspected through each ethical facet: (1) consequences and (2) virtues of the leader's actions and (3) the leader's ethical duties. The summary of our data is presented in Table 1. In the table below we have put forth managers, their gender, ages, professional positions and their overall background. In addition, durations of interviews are also presented.

TABLE 1. Summary of the empirical data - description of the interviewed managers. (TABLE 1 ISLOCATED HERE)

\section{Four types of manipulation in storytelling leadership}


The four types of manipulation are presented in this chapter. In each sub-chapter, we first define the idea and salient features of the type. Second, we provide one example story in a more detail and also describe the situation in which manipulative behaviour has taken place. Third, we will briefly consider other stories belonging to the type. Fourth, we will ponder situations and managers' intentions from an ethical perspective. To make it easier to distinguish between the stories, they are numbered from 1-13. In the analysis text we use references that indicate the narrator and the story in question. For example $(B, 1)$ refers to manager $B$ and story 1 . The pivotal findings of the analysis, including the numbering and excerpt of each story, are summarized in Table 2.

\subsection{H umorous manipulation}

Scholars, including philosophers, sociologists and psychologists have long attempted to develop a comprehensive theory of humour, but in vain (Stephenson 1951, pp. 569-574). Often humour is understood as a mood or where the subject is influenced by something considered as fanciful, comical, funny, odd or whimsical (Oxford English Dictionary). The discussions about humour have revolved around themes such as the functions of humour (what humour says about society), the problems of how to recognize various expressions of humour in different situations, and the influence of humour on its recipients (Knuuttila, 1992). The second theme overrides the two others in our study: we identified the humorous aspect from our data. We do not analyse the general role of humour in our society, and our data does not include information about reception and recipients. 
Generally humour or issues considered as ridiculous have had something to do with feeling of superiority, sudden changes of events (for example situation comedy), the simultaneous existence of opposites such as pleasantness and unpleasantness, joy and distress, greatness and insignificance. It is also typical for humour to indude some kind of element of tragedy because strong emotions are usually attached to humour. For example, some great accidents and disasters, such as the explosion of space shuttle Challenger in 1986 and the shipwreck of the Estonia in 1994, generated a crop of jokes, the purpose of which was to help people to cope with collective grief (cf. Oring 1987; Smyth 1986; Simons 1986). In addition, we can also identify humour by referring to the attitude of the narrator, i.e. what she or he considers as humorous or funny. Of course, there may be disagreement about what is considered funny between the narrator and his audience. (Knuuttila, 1992.)

In general, literature on humour suggest that stories as a means of humoristic discourse have several functions. Certain genres have been identified, such as entertaining anecdotes, demeaning rumours, educating stories with a moral and emancipative trickster stories. According to Gabriel and Griffiths (2004, 114), on a symbolic level stories are able to deliver and mediate concealed meanings, which may be precarious or risky in social situations. Instead of direct critique towards a manager, a story in a form of joke can transform it in and offer the opportunity to pronounce one's critical opinion. On the other hand a manager is also able to hide his critique in the form of a joke.

We identified four stories which can be considered humorous according to the content of the story and/ or the narrator's attitude. The stories deal with an ill-fated chef (B, 1), a 
thumbless chef $(H, 2)$, an innocuous engineer $(E, 3)$ and gender issues in a Balkan army $(F$, 4). The first one was selected as an example story for closer analysis. The form or genre of the stories varied from an anecd ote to a joke.

A hanged chef in the hotel

In this example the CEO (B) says that the experts of the company were dissatisfied with prevailing working conditions and conveniences. For example, they were complaining about having to travel economy class in airplanes and that they had to eat couscous or some other exotic food which they considered bad-tasting. Therefore, B decides to tell the following story to her employees.

\section{Extract 1, Manager B}

In A frica in the 70s they served a good breakfast every morning at this hotel. 0 utside the hotel conditions were so so, but back at the hotel everything was fine. H owever, one morning there was no breakfast, and so a guest began to wonder was going on, and went and took a peek into the kitchen - and found that the cook had been hanged.

The type of humour in the example story is rather gallows humour than innocent, goodhearted joking. The content of the story is not necessarily humorous, but our interpretation is based on the attitude of the narrator (B). Thus, although the story can be considered gruesome, the narrator considers it humorous herself. The classification of a story as humorous rests on the following issues. In the interview, B is laughing while telling and 
concluding the story. She also uses ridiculous utterances to send-up the situation. She refers for example to some employees' nagging wives.

The meaning of the humorous story type depends on the manner in which the story is recounted (Gabriel and Griffiths 2004). This example story is about very bad conditions at work. B's intention in telling this story to her employees is that one can work in poor conditions if one has the right attitude. The manager explained her motives in telling this story by stating that she has to encourage subordinates to adapt al so to poor conditions by raising a certain spirit in which they do not care about discomfort. She also thinks that her subordinates have become accustomed to very good conditions; unlike the people in the story. The function of the humorous story is educational and moral. Through the story employees are taught to respect their own working conditions more than now.

The type of manipulation is disinformation, because the manager exaggerates irrelevant and alien issues. An African chef hanged in the 1970's reflects current conditions in a Finnish company very indirectly. The manager appeals also to the employees' feelings of guilt and the shame for complaining about working conditions. Thus, she is using power indirectly while telling the story and negotiating about working conditions.

According to the B's own interpretation, she aimed to reduce the rumbles of discontent from the experts. Although the means to this end was peculiar, the goal was not completely unethical. Thus, from the storyteller's point of view this can be understood as belonging to the realm of consequence ethics. Telling the story was justified by the 
manager according to the positive results of action for the whole group of employees as well as the manager herself.

The ethics of the three other humorous stories share the same tendency as the example story. The main ethical principle is the consequences of the manager's action. Deontological ethics was absent in the humorous type of stories because the managers did not refer to any kind of duty, i.e. inner feeling or experience which demand them to act in a certain way. Virtue ethics is also quite absent in the stories, except in the second and third story which are told by the same manager (E). He describes himself as a benefactor who appreciates his followers' well being. In the other cases the storytellers treated their employees as means, not as ends, which is against the principles of virtue ethics.

To sum up all the four stories in this type, the humorous element of the stories is rather black humour, since the stories contain elements of tragedy (e.g. B, 1). The stories are identified as humorous due to the telling situation in the interview. In the story 1 the manager laughed herself while telling the story whereas stories 2 and 3 were jokes. Furthermore, story 4 was recognized as humorous since the manager $(F)$ said that the listeners laughed after hearing the story. Stories 1 and 3 were told with a view to reduce the dissatisfaction among employees and, besides, story 1 was intended to stimulate the feeling of being guilty among employees. Story 2 was told with a view to defuse conflict in a board meeting, where the participants were upset. E particularly aimed to influence his own superior, the CEO's behaviour. The purpose of story 4 was to increase motivation 
among servicemen. F preferred entertaining stimulation when he learned that commands and rational argumentation would not be that effective.

In terms of manipulation, stories 1 and 2 involve sharing disinformation. In story 1 there are no fal se statements whereas story 2 is an "old chestnut" that E doesn't even expect to be believed. Story 3 is straightforward lying while story 4 is about distributing misinformation. In the former case $\mathrm{E}$ reveals in the interview that he actually lied. The protagonist in story 4 is fictional character, but which according to the story is a real life person. From an ethical standpoint the stories 1,3 and 4 involve consequence ethics while story 2 indicates a touch of virtue.

\subsection{Pseudo-Participative manipulation}

In pseudo-participative manipulation the manager allows the subordinate to fallaciously feel that the manager is engaged in her/ his feelings and problems. Thus, the participation is more or less imaginary and one sided. We identified two stories which fulfil the demands of this type. The stories talk about a predetermined strategy of meeting and directing personnel by giving them a false conception of free choice. In the example story a manager leads employees to believe that they have found the solution to a problem by themselves. The story goes as follows.

O Idsmobile Car M anufacturer 
The organization suffers from lack of focus in its development work. The researchers have been used to studying quite freely, topics that they are interested in despite the strategic focus areas of the organization. Thus, research has become too fragmented and spread over too many areas. Although the researchers have been pressured to follow the strategy, they have been unwilling to give up their own research interests and projects.

\section{Extract 2, Manager F:}

The Oldsmobile car manufacturer had been experimenting with all kinds of alternative engines in its time. In those days there were steam engines and combustion engines of numerous different kinds. $\mathrm{He}$ had all of the potential engine technologies under development at the factory, but then luck had it that his factory burned down. And the fire destroyed everything except for a car that was driven by a petrol engine. A nd he no longer had any money to devel op the others, so the one and only thing he had left was the petrol engine, which was the technology that ultimately made the breakthrough. The point of my story is: what fire do we need to identify that single, clear focus. I've sought to ask them what would be the one thing they wished would survive. So this is one example of my storytelling in this field.

F's intention was to persuade the researchers to get rid of additional projects. He was worried about the technological development in the organization because it did not follow the new strategy. Furthermore, all the additional projects caused inefficiency.

$\mathrm{F}$ explained the reasoning behind the story by saying that he thinks the best way to commit people is to give them a feeling of being an essential part of the story. Instead of revealing the forthcoming imperative of reducing the areas of research, $F$ prefers disguised command (pseudo-participative) to coercion. In general he believes that researchers are 
particularly sensitive to strict commands. The type of manipulation is misinformation, because the information given to researchers is false at root and its purpose is to mislead. This is not about straightforward lying since the situation itself was as $\mathrm{F}$ described. However, the premise - the free choice to choose - is more or less false since $\mathrm{F}$ revealed later on in the interview that the organization, however, made them choose the appropriate technology to be developed sooner or later. Thus it is not about distributing disinformation either, which would require no fallacious information at all.

According to the manager $(F)$, this story did not evoke an immediate response in the organization, but the story was "lodged" in its collective memory. He emphasized that when the seed of an idea has been planted in an organization, it is easier to get a change through later. This is an example of consequence ethics since the aim of the manager was to produce a certain effect i.e. to change and define on-going research to fit better the research strategy in the organization by manipulating the employees.

The other story in this group is from banking sector. The bank CEO $(\mathrm{H})$ offered to his subordinates a notion about being a participant in the bank's strategy process. Furthermore, he also gave them a feeling of being empowered. He provided a concept for his subordinates about their freedom of choice and tried to avoid the impression that his orders came from above. In the strategy meeting, subordinates were given the opportunity to discuss the strategy and even suggest what topics should be emphasized and what was unimportant for the strategy. However, the management board had actually created and decided the themes to be discussed in meetings that had already taken place. Thus, the 
subordinates did not have a real and autonomous chance to participate in the strategy process. This made it a matter of pseudo-participative leadership and the type of manipulation in it, disinformation.

From the point of view of ethics, it is interesting to notice that the managers in both stories pointed out that instead of forcing, they believed in participatory and non-coercive influence. He even described himself as a coaching manager, who encourages his subordinates to act autonomously. This refers to virtuous conduct (and furthermore to virtue ethics), but as we presented above, the participation was affected and turned out to be pseudo-participation. Thus, it lacked integrity and honesty. This pattern also applies to the manager of the research organization who told the Oldsmobile story. He described himself as a manager who aims at being in dialogue with subordinates, but in the last resort he obstinately emphasizes the output. In conclusion, although there is a hint of virtue ethics, but this type is dominantly a matter of consequence ethics.

\subsection{Seductive manipulation}

From a narrator's point of view, stories can be considered panoptic in the sense that they are wholly transparent only from one direction. Thus they can be used to induce or even mislead listeners (Riessman, 2008; Gabriel 2008; Auvinen, 2012). Sole and Wilson (2002, 5) argue that stories are al so seductive by creating a 'truth' or real ity which is so delicate and vivid that the listeners cannot critically compare it to their own experiences. This can lead to a situation in which listeners are distracted from the storyteller's intention or purposes. In this sense, seductive manipulation refers to a situation in which employees are misled 
by a manager who tells them stories which misrepresent reality in too positive a manner. This type relates also to exaggeration and glibness. We identified four stories which fulfil the demands of this type. The following example comes from an educational institute.

Poppy Fabric Curtains

\section{Extract 3, Manager A}

I can give one example about the time we had to move very quickly into this house from the traditional place where our organization had been operating since -57. From whatever viewpoint, our schedule was extremely tight, like in terms of planning, actual moving and the whole development of the organization, and it began to irk me that people only saw negative things, like "oh, how terrible". Everybody was feeling sorry for us: "oh how terrible, you can't possible make it in that time". So I decided to put an end to that moaning from the outside, [I] took one of our training managers with me, and quite femininely went and bought 22 bolts of M arimekko's [a Finnish fabric company] "Poppy" fabric for curtains. A nd then, when people started asking - at that point I didn't even know how many windows we'd have or anything - when people started asking about how the renovation was coming along, I'd tell them I couldn't really say, "but the curtains have already been bought", which changed the situation around completely. (M anager B)

$A^{\prime}$ 's idea in the story is that she tries to inspire the personnel to adapt to a new working environment by manipulating issues related to the moving process. She is doing it by offering them the impression that the moving process is almost over, because the curtains are al ready there. This contains the idea that the house is just about finished, nothing is left to do, but to hang curtains in the windows and paintings on the walls. A is appealing to 
emotions by providing an attractive and promising interior for the organization. She is also exaggerating one single detail, the curtains, instead of other and maybe more important things. But, this is only an impression, an attempt to construct a desired organizational reality, because it is not guaranteed that this kind of environment will actually come about.

In this case the concerns of personnel are ignored such as the cultural and emotional bond to the old building and the challenges with the construction timetables of a new building are downplayed. On the contrary, the significance of a trivial furnishing detail is emphasized. However, from the manipulation point of view, A is actually not lying but rather misleading her employees. Disinformation here means creating an attractive impression for employees via false information that provides a misleading concept of the moving situation to the employees.

The ethics of the manager in the Poppy Fabric Curtain story can be delineated as belonging to the sphere of deontological ethics. A constructs herself as a leader who is strict in maintaining her own duties and responsibilities. She demands this from herself as well as from personnel. Thus she states that she calls for commitment from everyone. Her duty as the head of the organization is to be responsible for the economic health of the organization. Hence, purchasing the curtains is motivated by the duties she assign to herself, not by any kind of virtue. Besides, she considers the personnel, at least partly, as old fashioned. It is also possible to interpret the story as partly reflecting consequence ethics, because she is trying to reach certain outcome by her behaviour. 
In another example in our data there is a similar kind of element in a foreman's (E) speech. He works in the forestry industry and aspires to play down deficiencies in working circumstances.

\section{Extract 4, Manager E}

With storytelling and jokes I try to lighten the atmosphere in our working place. In fact the whole working climate is a scam... with the imagination of people we can construct a cosy working place inside this gloomy environment ... although that place; really, there is no chance you could consider it cosy.

In this case, too, the manager is in not lying directly but rather blotting out the negatives by telling overly positive stories about the working place. The type of manipulation is misleading. However, contrary to the Poppy Fabric Curtain manager, this manager's intentions are not based on duties stemming from a manager's duty to be responsible for financial performance, but from creating a positive attitude towards all people. He depicts himself as a cooperative and caring manager.

To sum up the four stories in this type, the seductive element has to do with exerting intentional manipulative influence on employees by a manager. In other words, the managers aim to construct a more appealing organizational reality. In terms of manipulation, the story 8 and 10 were about distributing misinformation since the managers did not actually lie but rather overemphasized the positive aspects while neglecting the negative ones. Story 9 involved distributing misinformation since the 
manager E did not resort to straightforward lying. However, he did provide false information about the nature of the prevailing working conditions. Story 7 can be considered lying since the original meaning of the story was not at all in accordance with the interpretation the employees adopted. In other words, A led them intentionally to live in a fallacy. From an ethical standpoint the stories 7, 9 and 10 have to do with consequence ethics while story 8 indicates duty ethics. Furthermore, in story 10 there is a trace of virtue ethics since manager 10 expressed her desire to cultivate humanity.

\subsection{Pseudo-empathetic}

By empathy we refer to the human capacity to participate emotionally in the experiences of other people (Schulman, 2002). Empathy includes multiple emotions, such as joy or sorrow, which people are able to feel by imagining psychologically themselves in another person's place (Goleman, 1995). Empathy also has connections to manifestations of power when empathy is understood as the management of another person's emotions. By pseudo-empathy we refer to similar kind of situation which occurred in the case of pseudo-participation, except that now manager pretends to share the feelings and emotions of an employee. Three stories in our research belong to this type.

Stories representing pseudo-empathetic manipulation share the arrangement where there is a particular contradiction/ juxtaposition between a manager and a subordinate. It is a matter of dismissal or redeployment, which means a crucial change for the subordinate. The element that makes a manager's empathy pseudo-empathy relates to a power and 
knowledge asymmetry. The organization is downsizing personnel and the Manager $\mathrm{G}$ has to execute this process. The manager possesses information which should be delivered to the workers, and based on this knowledge, he has the power to influence the emotions of employees in a dismissal situation. He aspires to avoid an open conflict in the situation and, on the other hand, to preserve workers' self-respect by manipulating subordinates in pseudo-empathetic manner.

The following case comes from a financial institute:

\section{Extract 5, Manager G}

I think I actually lied straight out in those situations. There were some clear situations, work fatigue or, should I say, lack of professionalism or laziness or, like in the case of a certain bank manager, time had just past him by. Even to them I'd say, "very accomplished", "good career" and "you've done a fine job" and so on, because it didn't cost me anything. Like "you've been really, really good bank manager" and if, if that would give them a little consolation. [... ] When we're talking about these fourteen [who were fired], well, well, some of them really believed themselves to be good bank managers and professionally competent. That is, they, like, couldn't fathom this, and to some it came as a downright surprise: why were they being fired? And I told all of them that everything had gone really well but that now this ranking just had to be done and so on. Just like that, like very... but the point is that people will always ask "why me", "what for", "what was the specific reason" they weren't chosen [to stay on].

It is obvious that pseudo-empathy is not a black-and-white case. Feelings of empathy and disregard are both present in the situation. Although we speak about pseudo-empathy, we are not denying that real and authentic empathy may appear too. It is a matter of 
managing emotions which requires perceiving and identifying other people's situation and emotions, which is a basic ethical skill of a leader (cf. Goleman, 1995).

Following extracts illustrates a discordant situation:

\section{Extract 6, Manager G}

For me, say, 'who cares', [... ] everything in that situation was like whitelies, [... ] if it just hel ps people.

\section{Extract 7, Manager G}

$\mathrm{H}$ aving to be in a situation like that, it's extremely tough when we're talking about jobs and talking about people as a whole... with their families and friends

\section{Extract 8, Manager I}

There is no reason to express strong realism when someone asks why his [contract] does not continue. So, you can't say, 'you're a lousy worker. (... ) you are a bozo and nobody likes you', even if this is true. So, if I left something unsaid, I have only softened the issue or lied lightly.

G resorted to lies when trying to carry out his approach to dismissing staff. He believes that many employees who had been made redundant, maintained positive, al though false, self-esteem and idea of themselves and their performance in the organization. The manager stretches morality by stating that he should give a softened rationale to fired 
subordinates, whether right or wrong, for the dismissal. The moral here is that it is better when fired employees believe that they were useful to the company even if this is misleading.

To sum up the stories in terms of manipulation, in the case of Manager $G$ the type of manipulation is lying and he does it a bit sleekly. The other managers in this group, $\mathrm{C}$ and I, swing between misinformation and disinformation. The variation in the types of manipulation, whether it is lying, misinformation or disinformation, does not matter here, because all managers aim not to insult employees who are facing redundancy.

From the point of view of ethics, the pseudo-empathetic manipulation is closely connected to consequence ethics. According to this, the purpose of a manager's actions is the greater good. Although it can be argued that dismissal does not represent the greatest good for employees, our focus is on manipulation, not on the ethics of the dismissal as such. When the dismissal is a compulsory action, managers try to minimize the harm caused to subordinates. The cost of this procedure is that they have to manipulate subordinates in pseudo-empathetic manner. When it comes to virtue ethics, managers do not act virtuously because their empathy also appears to be pretended and it also involves selfish behaviour. They do not manipulate subordinates because they consider themselves as virtuous managers, but instead, they also minimise their own burden. Thus, the absence of virtue ethics is a constituent of pseudo-empathetic manipulation. It is also a way for managers to survive in the extremely challenging situation of dismissals. 


\subsection{Summary of the results}

The aim in this article was to identify different types of manipulation in leadership storytelling. The summary of the results are presented in Table 2.

In the following table the situations, contents, modes of manipulation and ethical facets are presented.

TABLE 2. Summary of all stories - description of the types of manipulation.

(TABLE 2 WILL BE LOCATED HERE)

Overall, the study showed that manipulation in leadership storytelling is constructed by various manipulative types and forms and the use of manipulation in its different types and forms was familiar to several managers interviewed in this study. Some of them considered manipulation as an inescapable part of their work. Manipulation was said by the managers to belong to their everyday discursive routines and resources. However, manipulation did not seem to stand out as an especially distinctive part of leadership. The forms of manipulation which were distinguished were lying, providing misinformation and providing disinformation. Providing disinformation was the most common type. Out of thirteen stories, eight stories involved providing disinformation. In addition, there were three stories involving misinformation and two stories contained lying. 
The study showed that there are different ethical facets underlying the types of manipulation in leadership storytelling. The facets we used as a context for our analysis were consequence ethics, virtue ethics and duty ethics (Ciulla 2005; Ciulla and Forsyth 2011). Ethical reasoning of the managers' manipulation in storytelling seemed to involve typically consequence ethics with the other facets remaining scarce. However, in pseudoparticipative and pseudo-empathetic manipulation particularly a glimpse of virtue ethics also emerged. In pseudo-participative manipulation the managers explained that through their actions they tried to avoid authoritarian and coercive leadership. In pseudoempathetic manipulation the case was a somewhat humane treatment of dismissed subordinates. However, in terms of virtue ethics, all the types of manipulation contained an incontestable vice: dishonesty.

\section{Conclusions and discussion}

We observed four different types of manipulation in leadership storytelling in this study humorous, pseudo-participative, seductive and pseudo-empathetic - but others may be found as well. For example, it might be possible that threatening stories could be used by managers for the purposes of manipulation even if we did not find such stories in this study. Therefore, it would be important to investigate the topic more in the future by acquiring more various data sets than now from different social contexts.

Since leadership is a socially constructed relationship between two parties such as a manager and an employee (Fairhurst and Grant, 2010; Fairhurst, 2008, 2011), it would be 
naïve to assume that it is only the manager who manipulates the other party. Even if the manager has a power position and thus more opportunities for manipulation, it can be argued that employees who lack a formal power position and thus need indirect influence means, might be even more disposed to manipulate their managers than vice versa. This is a topic which is worth studying in the future. In general, power asymmetry based usually on a person's formal position and her/ his access to information is a topic of relevance to investigate in relation to manipulation in storytelling leadership.

In all four types of manipulation detected in this study, consequentialism emerged as a primary ethical justification. The finding lends support to a conclusion by many business ethics studies that it is common for managers to rely on consequence ethics in their reasoning (see Velasquez, 1998, p. 72; Kujala et al., 2011). Even if managers in this study said they had used manipulation in their leadership storytelling, most often they judged manipulative influence as negative. However, some took a bit more of a permissive attitude to the topic; others were somewhat mortified at having manipulated employees. In general, we think that the managers in this study cannot be considered completely sinners (cf. Bass, 1998) in their leadership. They had sometimes selfish intentions but also often a broader interest and good outcome guided their manipulation. For example, in many situations manipulative storytelling was viewed as a solution to soften the hard facts of a situation (Bass, 1998), avoid annoyance or grief and maintain a good atmosphere in an organization. 
The managers also found manipulative storytelling appropriate when it helped to avoid coercion. This suggests that the line between manipulation and inspiration as well as politeness can sometimes be hazy. Consequently, we conclude that some degree of manipulation in storytelling when intended to a good purpose may by acceptable in leadership. However we think that such storytelling requires from managers not only the right context and sensitive understanding of a situation and good social skills but also a genuine awareness of her/ his motivation to manipulate. Neither intention to insult or harm other people nor to use other people to a manager's own ends can be accepted in any leadership. Thus, this study shows that stories and storytelling can be used as a means for manipulation, because even hard messages can be conveyed in a soft mode by stories (cf. Gabriel 2008).

It is noteworthy that manipulative storytelling involves a risk for a manager herself/ himself. When she/ he is caught in a lie or stretching the truth, her/ his reputation as a leader can be lost and trust in her/ him is risked (Bass, 1998). Since trust is a crucial element in constructive relationships and trust of managers has been found to have an effect on employees' attitudes and performance (e.g. Jones and George, 1998; Connell et al., 2003), a manager's manipulation can also have negative organizational outcomes such as a cynical attitude among employees, irresponsibility in employees' work behaviour, and even alienation from the workplace. Bass (1998) argues that it is particularly leaders who are close to their followers who can lose reputation with just one episode of shading the truth. However, since he did not study the topic empirically, we suggest that this viewpoint merits further research. Another risk in using manipulation in storytelling 
leadership is that when applied occasionally and successfully it easily becomes a selfevident part of leadership and organizational life. Thus, here lies a risk for a toxic triangle in an organization involving a manipulative leader; a susceptible follower and also conducive organizational environment (cf. Padilla et al., 2007).

Even if manipulation in leadership can be regarded as a theoretical challenge, first and foremost it is a practical problem: what kind of stories do managers tell in practice to influence their employees and why? To be able to increase managers' awareness of their motives and harms related to manipulative behaviour, the content of management and leadership education is worth considering (e.g. Clements and Washbush, 1999). Developing a future manager to be aware of manipulative behaviour and its risks related to followers and an organization as well as the consequences to her/ his image as a leader and leadership in general can be fruitful. Consequently, we suggest that in educational contexts the phenomenon of manipulation in leadership from different viewpoints should be openly discussed and reflected upon. Students could be assigned to identify with and imagine themselves as to be objects of manipulation. Experiential teaching and learning methods are likely to be valuable here. At an organization level it would be worthwhile to consider typical situations which may invoke manipulative behaviour as well as to define explicitly values, politics and principles to be followed in leadership. Both a manager and employee should be aware of fundamental values and norms in their relationships.

Finally, the findings of this study must be viewed bearing in mind the limitations of the study. We conducted a qualitative research and could not investigate clear interrelations 
among for example manipulation in leadership and its outcomes to employees' performance and other organizational outcomes. This could be done using a quantitative study approach and statistical analysis. However, we think that we provided a rich view to manipulation in storytelling leadership and shed light on a phenomenon which has not been studied much empirically. Moreover, we are aware that the interviewed managers may have not told the most unethical manipulative stories to us as researchers but may have left them untold. That could have had an effect to our results so that the tune of the stories in this study is perhaps more positive than in practice

\section{References}

A honen, A. (2001). Organisaatio, johtaminen ja edistyksen puhekäytännöt: Liikkeenjohdollisen tiedon kentät, kerrostumat ja kulttuurinen paikka. [Organizations, management and the discourse of the progress.] Doctoral Dissertation., Turku School of Economics, Turku, Finland.

A uvinen, T. (2012). The Ghost Leader: An Empirical Study on Narrative Leadership. EJBO Electronic Journal of Business Ethics and Organization Studies 17 (1), 4-15.

Auvinen, T., Aaltio, I., and Blomqvist, K-M. (2012). Constructing Leadership by Storytelling - The Meaning of Trust and Narratives. Leadership and Organization Development Journal (forthcoming) 
Auvinen, T., Mangeloja, E., and Sintonen, T. (2010). Is Narrative a Content of Economics and Business Administration? An Essay about why Homo Economicus is actually Homo Narrans: From Realistic to Narrative Paradigm. Annual Review of Management and Organizational Inquiry. Tamaraland Publications, USA.

Bass, B.M. (1998). The Ethics of Transformational Leadership. In Joanne B. Ciulla (Ed.) Ethics. The Heart of Leadership, 169-192. Praeger, Westport.

Bass, B. M., and Steidlmeier, P. (1999). Ethics, character, and authentic transformational leadership behavior. The Leadership Quarterly 10 (2), 181-208.

Berger, P.L., and Luckmann, T. (1966). The Social Construction of Reality. Doubleday, N ew York.

Boje, D. (1991). The Storytelling Organization: A Study of Story Performance in an OfficeSupply Firm. Administrative Science Quarterly 36 (1), 106-126.

Boje, D. (1995). Stories of the Storytelling Organization: A Postmodern A nalysis of Disney as “Tamara-Land". A cademy of Management Journal 38 (4), 997-1035.

Boje, D. (1999). Storytelling leaders. On line: http:/ / business.nmsu.edu/ -dboje/ leaders.html [cited 15.3.2008.] 
Boje, D. (2001). Narrative M ethods for Organizational and Communication Research. Sage, Lontoo.

Boje, D. (2003a). Using Narrative and Telling Stories. In D. Holman and R. Thorpe. (eds.), Management and Language, (pp. 41-53). Sage, London

Boje, D. (2003b). Theatrics of Leadership: Leaders as Storytellers and Thespians. On line: http:/ / business.nmsu.edu/ - dboje/ teaching/ 338/ theatrics_of_leadership_links.htm) [cited 8.6.2010]

Boje, D. (2006). Book Review Essay: Pitfalls in Storytelling Advice and Praxis. A cademy of Management Review 31 (1), 218-230.

Boje, D., and Rhodes, C. (2006). The Leadership of Ronald McDonald: Double Narration and Stylistic Lines of Transformation. The Leadership Quarterly 17, 94-103.

Boje, D. (2008). Storytelling Organizations. Sage, London

Boje, D., Pullen, A., Rhodes, C., and Rosile, G. A. (2011). The Virtual Leader. In A. Bryman, D. Collinson, K. Grint, B. Jackson, and M. Uhl-Bien (eds.), Sage Handbook of Leadership, (pp. 518-529). Sage Publications, London. 
Bok, S. (1981) [1978]. Miksi Valehtelemme [Lying: Moral Choice in Public and Private Life]. Jyväskylä: Gummerus Osakeyhtiö.

Brand, V. (2009). Empirical Business Ethics Research and Paradigm A nalysis. Journal of Business Ethics 86, 429-449.

Brown, A. D., Gabriel, Y. and Gherardi, S. (2009). Storytelling and Change: An Unfolding Story. Organization 16 (3), 323-333.

Brown, J., Groh, K., Prusak, L. and Denning. S. (2005). Storytelling in Organizations. Butterworth-Heinemann, UK.

Brown, M.E. and Trevinõ, L.K. (2006). Ethical leadership: A review and future directions. The Leadership Quarterly 17, 595-616.

Bruner, J. (1991). The Narrative Construction of Reality. Critical Inquiry 18 (Autumn), 1-21.

Bryman, A. and Bell, E. (2007). Business research methods. Oxford University Press. Oxford.

Carson, T. L. (1988). On the Definition of Lying: A Reply to Jones and Revisions. Journal of Business Ethics 7, 509-514. 
Ciulla, J. B. (1998). Leadership Ethics: Mapping the Territory. In J. B. Ciulla (Ed.) Ethics. The H eart of Leadership, (pp. 1-25). Praeger, Westport.

Ciulla, J. B. (2005). The State of Leadership Ethics and the Work that Lies Before Us. Business Ethics: A European Review 14, 323-335.

Ciulla, J. B. and Forsyth, D. R. (2011). Leadership Ethics. In A. Bryman, D. Collinson, K. Grint, B. Jackson and M. Uhl-Bien (Eds.) The Sage Handbook of Leadership (pp. 229-241) Sage, London.

Clements, C. and Washbush, J. B. (1999). The two faces of leadership: considering the dark side of leader-follower dynamics. Journal of Workplace Learning 11, 170-175.

Collinson, C. and Mackenzie, A. (1999). The Power of Story in Organisations. Journal of Workplace Learning 11 (1), 38-40.

Connell, J., Ferres, N. and Travaglione, T. (2003). Engendering trust in managersubordinate relationships. Predictors and outcomes. Personnel Review 32, 569-587.

Crane, A. and Matten, D. (2004). Business Ethics: A European Perspective. Oxford University Press, Oxford.

Dennehy, R. (1999). The Executive as Storyteller. Management Review 88 (3), 40-43. 
Denning, S. (2004). Telling tales. Harvard Business Review 82 (5), 122-129.

Denning, S. (2005). The Leader's Guide to Storytelling. Jossey-Bass. San Francisco, USA.

Dick, P. K. (1978). How To Build A Universe That Doesn't Fall A part Two Days Later. A vailable Online: http:/ / deoxy.org/ pkd_how2build.htm [Cited 1.10.2011]

Driscoll, C. and McKee, M., (2007). Restorying a Culture of Ethical and Spiritual Values: A Role for Leader Storytelling. Journal of Business Ethics 73, 205-217

Eriksson, P. and Kovalainen, A, (2008). Qualitative Methods in Business Research. Sage, London.

Eskola, J. and Suoranta, J. (1998). Johdatus laadulliseen tutkimukseen. [Introduction to Qualitative Research]. Vastapaino, Tampere, Finland.

Fairhurst, G.T. (2008). Discursive leadership: a communication alternative to leadership psychology. Management Communication Quarterly 21, 510-521.

Fairhurst, G.T. (2011). Discursive A pproaches to Leadership. In A. Bryman, D. Collinson, K. Grint, B. Jackson and M. Uhl-Bien (Eds.) The Sage Handbook of Leadership. (pp. 495517) Sage, London. 
Fairhurst, G.T. and Grant, D. (2010). The social construction of leadership: A sailing guide. Management Communication Quarterly 24, 171-210.

Fisher, W. R. (1985). The N arrative Paradigm: In the Beginning. Journal of Communication 35 (4), $74-89$.

Foucault, M. 1980 [1975]. Tarkkailla ja rangaista [Surveiller et punir]. Otava, Helsinki.

Gabriel, Y. (1995). The Unmanaged Organization: Stories, Fantasies and Subjectivity. Organization Studies 16 (3), 477-501.

Gabriel, Y. (2000). Storytelling in Organizations: Facts, Fiction and Fantasies. Oxford University Press, Oxford.

Gabriel, Y. (2008). Seduced by the text: The desire to be deceived in story, memoir and drama. Tamara Journal 7 (2), 154-167.

Gabriel, Y. and Griffiths, D. S. (2004). Stories in Organizational Research. In C. Cassell and G, Symon (eds.) Essential Guide to Qual itative Methods in Organizational Research. Sage, London.

Gergen, M. and Gergen, K. (2006). Narratives in Action. Narrative Inquiry 16 (1), 112-121. 
Goleman, D. (1995). Emotional Intelligence. Bloomsbury, Great Britain.

Jameson, D. (2001). N arrative Discourse and Management Action. The Journal of Business Communication 38 (4), 476-511.

Jones, G. R. and George, J. F. (1998). The experience and evolution of trust: Implications for cooperation and teamwork. Academy of Management Review 23, 531-546.

Kets de Vries, M., (1993). Leaders, Fools and Imposters: Essays on the Psychology of Leadership. Jossey-Bass, San Francisco.

Knuuttila, S. (1992). Kansanhuumorin mieli. Kaskut maailmankuvan aineksina. [The mind of folk humour]. SKS, Helsinki, Finland.

Kujala, J., Lämsä, A-M . and Penttilä. K. (2011). Managers' moral decision-making patterns over time: A multidimensional approach. Journal of Business Ethics 100 (2), 191-207.

Lämsä, A-M. and Sintonen, T. (2001). A Discursive Approach to Understanding Women Leaders in Working Life. Journal of Business Ethics 34 (3-4), 255-267.

Lauerma, H. (2006). Usko, Toivo ja Huijaus [Belief, Hope and Swindle]. Gummerrus Kirjapaino Oy, Jyväskylä. 
Lehtonen, M. (2004). Merkitysten maailma: Kulttuurisen tekstintutkimuksen lähtökohtia. [The world of meanings]. Vastapaino, Tampere.

Lukes, S. (2005). Power. A Radical View. Palgrave Macmillan, Basingstone, Hampshire and New York.

Maclntyre, A. (2007) [1981]. Hyveiden jäljillä. (After Virtue: A Study in Moral Theory). Gaudeamus Helsinki University Press, Helsinki, Finland.

McClelland, D. C. (1970). The two faces of power. Journal of International Affairs, 24, 2947.

Mills, C. W. (1990) [1959]. Sosiologinen mielikuvitus [The Sociological Imagination]. Tutkijaliitto, Helsinki.

Molinsky, A. and Margolis, J. (2005). Necessary evils and interpersonal sensitivity in organizations. Academy of Management Review 30, 245-268.

Oring, E. (1987). Jokes and the Discourse on Disaster. The Journal of American Folklore. 100 (397), 276-286.

Oxford English Dictionary. Online version (http:/ / oxforddictionaries.com). [cited 
14.5.2012]

Padilla, A., Hogan, R. and Kaiser, R. B. (2007). The toxic triangle: Destructive leaders, susceptible followers and conducive environments. The Leadership Quarterly. 18 (3), 176194.

Parkin, M. (2004). Using Storytelling to Develop People and Organizations. Kogan Page Limited, London, UK and Sterling, USA.

Parry, K. and Hansen, H. (2007). Organizational Story as Leadership. Leadership 3 (3), 281300.

Patton, M. Q. (2002). Qualitative research and evaluation methods, 3rd edition, Sage, Thousand Oaks.

Peters, T. (1990). Get Innovative or Get Dead. California Management Review 33 (2), 9-23.

Polkinghorne, D. E. (1988). Narrative Knowing and the Human Sciences. State University of New York Press. Albany, USA.

Polkinghorne, D. E. (1995). Narrative configuration in qualitative analysis. Qualitative Studies in Education 8(1), 5-23.

Polkinghorne, D. E. (2007). Validity Issues in N arrative Research. Qualitative Inquiry 
$13(4), 471-486$.

Poulton, M. S. (2005). Organizational Storytelling, Ethics and Morality: How Stories Frame Limits of Behavior in Organizations. Electronic Journal of Business Ethics and Organization Studies 10 (2), 4-9.

Riessman, C. K. (2008). N arrative Methods for the Human Sciences. Sage, London.

Rhode, D. (2006). Introduction: Where Is the Leadership in Moral Leadership. In D. Rhode (ed.) Moral Leadership. The Theory and Practice of Power, Judgment, and Policy. (pp. 153). J ossey-Bass, San Francisco.

Rost, J. (1993). Leadership for the Twenty-First Century. Praeger, London.

Sauer, E., Ropo, A., Mikkonen, A-M. and Salovaara, P. (2010). Johtajuuden Uusi Taide. [The N ew Art of Leadership]. Tampere University Press, Tampere, Finland.

Schulman, M. (2002). How We Become Moral. The Sources of Moral Motivation. In C.R. Snyder and S. J. Shane (eds.) Handbook of Positive Psychology. (pp. 499-512) Oxford University Press. New York

Simons, E. R. (1986). The NASA Joke Cycle: The Astronauts and the Teacher. Western Folklore 45 (4), 261-277. 
Sintonen, T. and Auvinen, T. (2009). Who is Leading, Leader or Story? The Power of Stories to Lead. Tamara J ournal 8 (1), 95-109.

Smyth, W. (1986). Challenger Jokes and the Humor of Disaster. Western Folklore 45 (4), 243-260.

Sole, D. and Wilson, D.G (2004). Storytelling in Organizations: The power and traps of using stories to share knowledge in organizations. From LILA Harvard University Web Site:

http:/ / www.providersedge.com/ docs/ km articles/ Storytelling in Organizations.pdf [cited 1.1.2007]

Stephenson, R. M. (1951). Conflict and Control Functions of Humor. American Journal of Sociology 56 (6), 569-574.

Steinar, K. (2007). Doing Interviews. Sage, London.

Søderberg, A . (2003). Sensegiving and sensemaking in an integration process: A narrative approach to the study of an international acquisition. In B. Czarniawska and P. Gagliardi (Eds.), N arratives we organize by (pp.3-35). John Benjamins Publishing, Philadel phia. 
Taylor, S. S., Fisher, D. and Dufresne R. L. (2002). The Aesthetics of Management Storytelling: A Key to Organizational Learning. Management Learning 2002, 33; 313

Tierney, P. and Tepper, B. J. (2007). Introduction to The Leadership Quarterly special issue: Destructive leadership. (Editorial). The Leadership Quarterly 18 (3), 171-173.

Velasquez, M. G. (1998). Business Ethics. Concepts and Cases. 4th edition. Prentice Hall, Upper Saddle River.

Weick, K. E. (1995). Sensemaking in Organizations. Sage Publications, USA

Weick, K. E. and Browning, L. D. (1986). Argument and Narration in Organizational Communication. Yearly Review of Management of the Journal of Management 12 (2), 243259.

Wicks, A. C., Berman, S. I. and Jones, T. M. (1999). The structure of optimal trust: moral and strategic implications. Academy of Management Review 24 (1), 99-116.

Wrong, D. (2004). Power. Its Forms, Bases and Uses. Basil Blackwel, London.

Yukl, G. (2010). Leadership in Organizations. Prentice-Hall, U pper Saddle River. 
TABLE 1. Summary of the empirical data - description of the interviewed managers.

\begin{tabular}{|c|c|c|c|c|}
\hline \multicolumn{4}{|c|}{$\begin{array}{l}\text { BACKROUND } \\
\text { INFORMATION }\end{array}$} & \multirow{2}{*}{$\begin{array}{l}\text { Data } \\
\text { Duration } \\
\text { of the } \\
\text { interview }\end{array}$} \\
\hline M anager & $\begin{array}{c}\text { G ender } \\
/ \\
\text { Age }\end{array}$ & $\begin{array}{l}\text { Position / } \\
\text { Line of } \\
\text { business }\end{array}$ & $\begin{array}{l}\text { Background (education and working experience) and self- } \\
\qquad \text { image as a leader }\end{array}$ & \\
\hline A & $\begin{array}{c}\text { Female } \\
\text { / } \\
50\end{array}$ & $\begin{array}{l}\text { Manager / } \\
\text { Education }\end{array}$ & $\begin{array}{l}\text { Bachelor in business admi nistration. Has worked for the same } \\
\text { employer for } 20 \text { years. Has some experience as an } \\
\text { entrepreneur in IT field. Describes own leadership style as } \\
\text { non-bureaucratic, participatory, straightforward and } \\
\text { trustworthy. Gives plenty of feedback. }\end{array}$ & 1 hour \\
\hline B & $\begin{array}{c}\text { Female } \\
\text { / } \\
45\end{array}$ & CEO / & $\begin{array}{l}\text { M.Sc. (for) and B.Sc. (econ). Has worked for more than } 20 \\
\text { years in forestry industry. Started as consultant and ended up } \\
\text { as CEO in fairly sizeable consulting firm. Describes own } \\
\text { leadership style as "narrative" and says that "leadership is } \\
\text { essentially about being involved with people". }\end{array}$ & $\begin{array}{c}1 \text { hour } 15 \\
\min \end{array}$ \\
\hline C & $\begin{array}{l}\text { Female } \\
\text { / } 55\end{array}$ & $\begin{array}{l}\text { Human } \\
\text { resource } \\
\text { manager / } \\
\text { Public } \\
\text { sector }\end{array}$ & $\begin{array}{l}\text { M.A. in economics. Has worked in public sector in different } \\
\text { roles, nowadays as a human resource manager in a large } \\
\text { municipal organization. Describes own leadership styleas } \\
\text { empathic, interactive and participative but aware of own } \\
\text { responsibilities. }\end{array}$ & $50 \mathrm{~min}$ \\
\hline D & $\begin{array}{l}\text { Female } \\
\text { / } 50\end{array}$ & $\begin{array}{l}\text { Manager / } \\
\text { Municipal } \\
\text { company }\end{array}$ & $\begin{array}{l}\text { Bachelor of arts. Has worked as a teacher for } 15 \text { years; } \\
\text { advanced from kindergarten manager to the head of a pre- } \\
\text { school cluster. Describes herself as an upright and impartial } \\
\text { leader, listens to her subordinates. Prefers a softer approach } \\
\text { leadership but can be hard and fast when needed. }\end{array}$ & $45 \mathrm{~min}$ \\
\hline
\end{tabular}




\begin{tabular}{|c|c|c|c|c|}
\hline E & $\begin{array}{c}\text { Male / } \\
65\end{array}$ & $\begin{array}{l}\text { Foreman } \\
\text { (retired) / } \\
\text { Forest } \\
\text { industry }\end{array}$ & $\begin{array}{l}\text { Vocational school. Has worked more that } 35 \text { years for the } \\
\text { same employer. Many different tasks and positions, e.g. } \\
\text { worker, shop steward and foreman in plywood mill. } \\
\text { Describes own leadership styleas humane, tries to avoid } \\
\text { authoritarianism. }\end{array}$ & 1 hour \\
\hline $\mathrm{F}$ & $\begin{array}{c}\text { Male/ } \\
35\end{array}$ & $\begin{array}{l}\text { Business } \\
\text { manager / } \\
\text { High-tech } \\
\text { research }\end{array}$ & $\begin{array}{l}\text { M.A. in business economics. Has worked as a marketing } \\
\text { manager in forestry industry for } 5 \text { years and for the last } 5 \\
\text { years in a high-tech firm. Describes own leadership style as } \\
\text { persuasive and non-coercive and emphasizes the meaning of } \\
\text { organizational stories. }\end{array}$ & $\begin{array}{c}1 \text { hour } 20 \\
\min \end{array}$ \\
\hline G & $\begin{array}{c}\text { Male/ } \\
\quad 45\end{array}$ & $\begin{array}{l}\text { Local } \\
\text { manager / } \\
\text { Banking }\end{array}$ & $\begin{array}{l}\text { Lawyer. Has worked for almost } 20 \text { years in a fairly sizeable } \\
\text { bank. Many positions and quick career advancement in } \\
\text { management in the same organisation. Describes his own } \\
\text { leadership style as participatory and democratic. }\end{array}$ & $\begin{array}{c}1 \text { hour } 35 \\
\text { min }\end{array}$ \\
\hline $\mathrm{H}$ & $\begin{array}{c}\text { Male/ } \\
60\end{array}$ & $\begin{array}{l}\text { CEO / } \\
\text { Banking }\end{array}$ & $\begin{array}{l}\text { M.A. in sociology. Has worked more than } 30 \text { years for the } \\
\text { same employer. Has advanced from local office manager to } \\
\text { CEO of large financial group. Prefers non-coercive leadership. }\end{array}$ & $\begin{array}{c}1 \text { hour } 10 \\
\min \end{array}$ \\
\hline I & $\begin{array}{c}\text { Male / } \\
55\end{array}$ & $\begin{array}{l}\text { Regional } \\
\text { manager / } \\
\text { Public } \\
\text { sector }\end{array}$ & $\begin{array}{l}\text { Lawyer. Has worked for a long period in the banking sector as } \\
\text { a manager, expert and attorney. N owadays works as a } \\
\text { regional manager in a large public sector organization. } \\
\text { Describes his leadership style as supportive and undisguised. } \\
\text { "An organization is like a sports team: Everyone has her/ his } \\
\text { own role to fulfil." }\end{array}$ & $1 \mathrm{~h} 45 \mathrm{~min}$ \\
\hline
\end{tabular}




\section{TABLE 2. Summary of all stories - description of the types of manipulation.}

\begin{tabular}{|c|c|c|c|c|c|}
\hline HUMOROUS & Mgr & $\begin{array}{c}\text { The content of the story in } \\
\text { nutshell }\end{array}$ & $\begin{array}{l}\text { The situation (why } \\
\text { the story was told) }\end{array}$ & $\begin{array}{l}\text { The form of } \\
\text { manipulation }\end{array}$ & $\begin{array}{c}\text { Ethical facet of } \\
\text { the leaders } \\
\text { actions }\end{array}$ \\
\hline $\begin{array}{l}\text { 1. A hanged chef } \\
\text { in the hotel. }\end{array}$ & B & $\begin{array}{l}\text { "A senior consultant was staying } \\
\text { in a hotel in A frica in 1970's. One } \\
\text { morning, there were no breakfast } \\
\text { in the hotel - because the chef was } \\
\text { hanged." }\end{array}$ & $\begin{array}{l}\text { Dissatisfaction in } \\
\text { prevailing working } \\
\text { conditions }\end{array}$ & Disinformation & Consequence \\
\hline $\begin{array}{l}\text { 2. A chef } \\
\text { without thumbs } \\
\text { in the old day in } \\
\text { a logging cabin. }\end{array}$ & E & $\begin{array}{l}\text { "I know a kind of worker we } \\
\text { need. In the old days in a logging } \\
\text { cabin there was a short-armed } \\
\text { chef without thumbs. He } \\
\text { couldn't scratch his butt or soak } \\
\text { his thumbs in the bowl." }\end{array}$ & $\begin{array}{l}\text { E tries to defuse the } \\
\text { conflict in the } \\
\text { board meeting. }\end{array}$ & Disinformation & Virtue \\
\hline $\begin{array}{l}\text { 3. A less } \\
\text { harmful } \\
\text { engineer }\end{array}$ & E & $\begin{array}{c}\text { And old sarcastic and also } \\
\text { obscene joke about a newlyweds } \\
\text { who wanted to make a kid that } \\
\text { would be an engineer. An } \\
\text { attempt failed and another } \\
\text { harmful engineer was not born. }\end{array}$ & $\begin{array}{l}\text { The employees } \\
\text { blame the } \\
\text { management for } \\
\text { the failed renewal } \\
\text { in the production } \\
\text { line. }\end{array}$ & Lying & Consequence \\
\hline $\begin{array}{l}\text { 4. Croatian } \\
\text { female guerrilla }\end{array}$ & $\mathrm{F}$ & $\begin{array}{l}\text { "Oncel knew a Croatian female } \\
\text { guerrilla who was able to } \\
\text { assemble and disassemble this } \\
\text { rifle in } 15 \text { seconds. I would think } \\
\text { you can do better than that." }\end{array}$ & $\begin{array}{l}\text { F stimulates } \\
\text { servicemen's } \\
\text { motivation with } \\
\text { humorous story. }\end{array}$ & Misinformation & Consequence \\
\hline
\end{tabular}

\section{PSEUDO PARTICIPATIVE}

\begin{tabular}{|c|c|c|c|c|c|}
\hline $\begin{array}{l}\text { 5. A nnual } \\
\text { strategy }\end{array}$ & $\mathrm{H}$ & $\begin{array}{l}\text { The executive group has prepared } \\
\text { the organization's strategy and }\end{array}$ & $\begin{array}{l}\mathrm{H} \text { aims to involve } \\
\text { the whole }\end{array}$ & Disinformation & $\begin{array}{l}\text { Consequence + } \\
\text { pseudo virtue }\end{array}$ \\
\hline meeting day & & annual plan. They want to outline & operative & & \\
\hline
\end{tabular}


create a vision by having the

entire organization participate. the strategy

process.

\begin{tabular}{|c|c|c|c|c|c|}
\hline 6. Oldsmobile & $\mathrm{F}$ & "Oldsmobile car manufacturer & F aims to make & & Consequence + \\
\hline car & & was fortunate to have a fire in its & employees follow & Misinformation & pseudo virtue \\
\hline manufacturer & & factory. The fire destroyed all & the strategy and get & & \\
\hline & & different engines except the petrol & rid of ineffective & & \\
\hline & & engine which eventually made & research. & & \\
\hline
\end{tabular}

\section{SEDUCTIVE}

7. cut-glass chandelier

A The staff were interested in a new

A aims to improve

Lying

Consequence cut-glass chandelier. According to the working one subordinate's story $A$ is so satisfaction among generous that she even bought a employees.

cut-glass chandelier that has

"those healing gleam and beams and everything".

8. Poppy fabric for curtains

9. Poor working E

E S

A $\quad[\mathrm{P}]$ eople only saw the negative things... [saying] you can't possible make it in that time...

[I]... went and bought 22 bolts of fabric for curtains... I'd tell them... the curtains have al ready been bought" circumstances
Seral stories about E's youth in

the factory and also amusing

anecdotes about life in general.

"With an imagination you can

construct that cosy working

place"
Employees suffer

Disinformation

Duty

from insecurity and

are in afraid of

change.

The working

Misinformation

Consequence circumstances are

appalling. E aims

to improve the

working

satisfaction. 


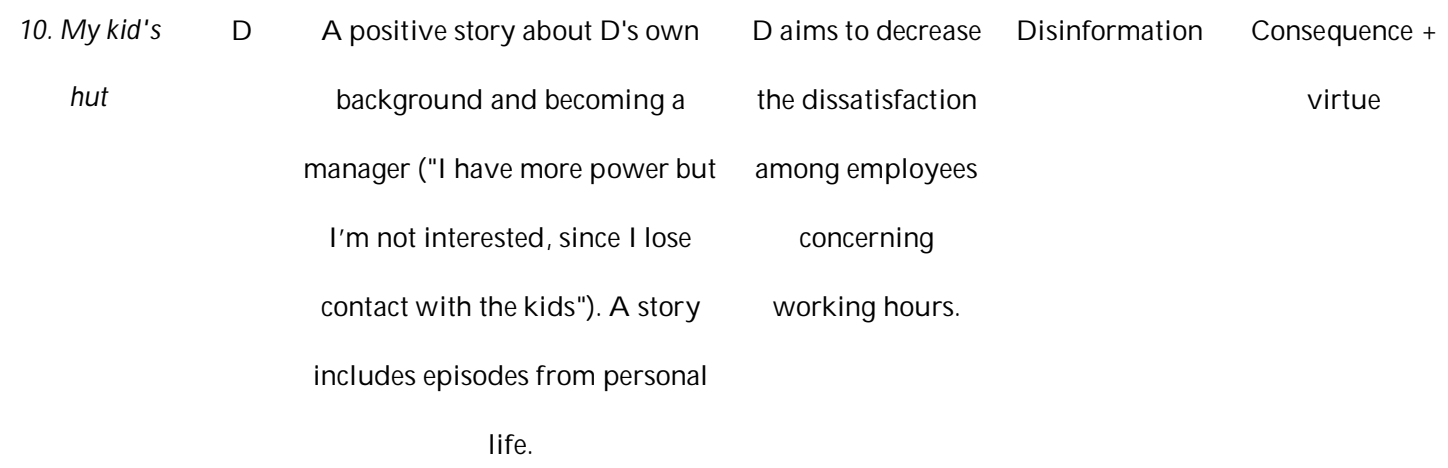

\section{PSEU D O-EM PHATETIC}

\begin{tabular}{|c|c|c|c|c|c|}
\hline 11. The lies of & G & Reflecting on a subordinate's past & The situation of & Lying / & Consequence + \\
\hline angels & & $\begin{array}{l}\text { in the organization. The story } \\
\text { indicate how excellent the } \\
\text { subordinate to be fired has been. } \\
\text { "you've done a fine job" in an } \\
\text { overly positive sense. }\end{array}$ & $\begin{array}{l}\text { dismissal is very } \\
\text { challenging. G lies } \\
\text { with a view to keep } \\
\text { the employees face } \\
\text { and self-dignity. }\end{array}$ & misinformation & pseudo virtue \\
\hline $\begin{array}{l}\text { 12. Tearful } \\
\text { subordinate }\end{array}$ & I & $\begin{array}{l}\text { "The timing of firing is excellent } \\
\text { and your future looks } \\
\text { prominent." N egative stories } \\
\text { about subordinate's past and } \\
\text { performance in the organization } \\
\text { are tempered. }\end{array}$ & $\begin{array}{c}\text { 'I' feels that a } \\
\text { miserable, } \\
\text { dismissed } \\
\text { employee needs to } \\
\text { be encouraged }\end{array}$ & Disinformation & $\begin{array}{c}\text { Consequence }+ \\
\text { virtue }\end{array}$ \\
\hline $\begin{array}{l}\text { 13. Dyslexic } \\
\text { supervisor }\end{array}$ & C & $\begin{array}{l}\text { The "openly recalled" story about } \\
\text { subordinate's merits and also } \\
\text { failures. The major reason for the } \\
\text { redeployment (dyslexia), is, } \\
\text { however, "intervieweetrailed off" }\end{array}$ & $\begin{array}{l}\text { In a redeployment } \\
\text { situation } C \text { is not } \\
\text { able to be frank } \\
\text { due to labour } \\
\text { legislation. }\end{array}$ & Disinformation & $\begin{array}{c}\text { Duty } \\
\text { (deontology) }\end{array}$ \\
\hline
\end{tabular}

